\title{
Proceeding
}

Supplementary Issue: Winter Conferences of Sports Science. Costa Blanca Sports Science Events, 22-23 March 2021. Alicante, Spain.

\section{Physical condition and eating habits in Physical Education students}

ANWAR JULIO YARIN-ACHACHAGUA , LUCÍA MIREYA SORIA-VILLANUEVA, MARCO ANTONIO TEJADA-MENDOZA, MANUEL JESUS ARISTA-HUACO

San Marcos National University, Peru

\begin{abstract}
The study analysed the association between physical condition and eating habits in physical education students from a Peruvian public university. The information was collected through the survey technique and physical tests in a sample that consisted of a total of 337 students, $60.2 \%$ from the morning shift and $39.8 \%$ from the night shift. The data was processed using SPSS v. 24. The results indicated a positive and significant correlation between physical tests and healthy eating habits $(p<.05)$; in the same way, a higher frequency of consumption was obtained in snacks, fried foods, etc. $(p<.05)$ in the night shift students, unlike the morning shift students who more frequently consume fruits, vegetables, homemade food, among others $(p<$ .05). Regarding physical condition, there was an indirect and significant correlation with eating habits $(p<$ .05). It is concluded that the management carried out to improve physical tests in students will be reflected in better eating habits; likewise, it is recommended to provide the corresponding importance in terms of the study variables.

Keywords: Physical condition; Eating habits; Physical tests.

\section{Cite this article as:}

Yarin-Achachagua, A.W., Soria-Villanueva, L.M., Tejada-Mendoza, M.A., \& Arista-Huaco, M.J. (2021). Physical condition and eating habits in Physical Education students. Journal of Human Sport and Exercise, 16(3proc), S988-S995. https://doi.org/10.14198/jhse.2021.16.Proc3.15
\end{abstract}

Corresponding author. National University of San Marcos, Peru. https://orcid.org/0000-0003-2369-129X

E-mail: anwar.yarin@unmsm.edu.pe

Abstract submitted to: Winter Conferences of Sports Science. Costa Blanca Sports Science Events, 22-23 March 2021. Alicante, Spain.

JOURNAL OF HUMAN SPORT \& EXERCISE ISSN 1988-5202.

(c) Faculty of Education. University of Alicante.

doi:10.14198/jhse.2021.16.Proc3.15 


\section{INTRODUCTION}

The requirement of constant monitoring of the physical condition of a student appears in the context of the biological development of nature and advancement of motor functions in conditions of difficult interaction with the environment (Yarmak et al., 2018); however, physical activity is reduced after high school (Kilpatrick et al., 2005; Burke et al. 2006). Nonetheless, food consumption habits are developed from childhood and are consolidated in youth and adulthood; this transition has various implications, which is why eating habits in university students is a challenge due to the changes in lifestyles that it entails (Burriel et al., 2013; El Ansari et al., 2012).

In Peru, sedentary lifestyle is present from childhood and is maintained in the course of intellectual training until professional life (Navarrete et al., 2019), this increases if the student suffers from chronic diseases, such as obesity (Pajuelo, 2017; Janssen et al., 2004), diabetes (Atamari et al., 2018), mental disorders (Beiter et al., 2015; Mori, 2000), among others.

In addition to the aforementioned, in the context of the coronavirus pandemic (COVID-19), the lifestyle of university students has been modified due to social immobilization (López et al., 2020) and the consequent risk of sedentary behaviours (Di Renzo et al., 2020), alcohol and tobacco consumption (Balanzá et al., 2020), as well as health effects (Mattioli et al., 2020). For this reason, it is convenient for young people to lead a healthy lifestyle, with special emphasis on university students (Papadaki et al., 2007).

Since there are no studies that analyse the physical condition and eating habits in relation to the morning and night shift classes in a Peruvian state university. The present study aims to identify the physical condition and eating habits per morning and night shift, compare the variables and dimensions per morning and night classes; in addition to determine the relationships between the variables and dimensions in the students of the Physical Education career at a public university in Lima in the context of pandemic.

\section{METHOD}

\section{Participants}

The sample was of the probabilistic type and consisted of 337 students in the academic period 2020-1,60.2\% of the morning shift and $39.8 \%$ of the night shift, being $63.8 \%$ men and $36.2 \%$ women aged between 17 and 28 years old, with an average of $22.3(\mathrm{SD}=2.76)$. According to the academic cycle, the most prevalent is the first cycle with $22.6 \%$, followed by the 2nd and 3rd cycle with $18.4 \%$ and $11.6 \%$, respectively, together with $47.4 \%$ of the remaining cycles. A probabilistic sample According to Sheppard (2020) refers to the sampling techniques for which the probability that a person or event is selected to be a member of the sample is known.

\section{Measurements}

For the physical condition variable, the physical education tests described by the Ministry of Education of Chile were used, which were validated and standardized nationally and internationally (Agency for the Quality of Education, 2014). The test consists of 4 parts: 1 . Anthropometry that details the dimensions of the individual, in this way the BMI was calculated from the height and weight of each student. Likewise, the ratio of waist circumference with height was calculated, this allows a prediction of cardiovascular risk factors (Ulijaszek and Mascie-Taylor, 2005). 2. Muscular performance, in this case the short abdominals, long jump with feet together and flexion-extension of the elbows were evaluated (Basco, 2014). 3. Flexibility, where 
forward trunk flexion is evaluated (Draga et al., 2020) and 4. Cardiorespiratory endurance, where the Course Navette test was evaluated (García and Secchi, 2014).

For the variable eating habits, the survey by Durán et al. (2014) was taken into consideration, who validated it by a total of 25 experts through the Delphi method. The questionnaire consisted of 2 parts: first, 9 questions under a Likert scale where the frequency of healthy habits was indicated, as well as the frequency of recommended foods (dairy, fruits, vegetables, among others). Second, 6 questions in relation to those foods that promote chronic diseases such as sugary drinks, alcohol, fast food, etc.

\section{Procedures}

In order to obtain the information, the students of the Physical Education Career of a public university located in Metropolitan Lima were contacted by email. The physical tests were carried out in the open field, while the eating habits questionnaire was applied virtually through google forms. Also, participation in the investigation was voluntary, taking informed consent into consideration; likewise, anonymity and confidentiality were reserved in the responses to the questionnaire and physical evidence.

\section{Analysis of data}

First, a descriptive and normality analysis (Kolmogorov-Smirnov) of the variables physical condition and eating habits was carried out, obtaining the average values and the standard deviation. Then, to estimate the differences between the first and second shift, contrast tests were applied for the independent samples (Student's T).

Finally, in order to establish relationships between anthropometry, physical tests and eating habits, we applied Pearson's correlation tests on normal distributions and Spearman's test on non-normal distributions. For data analysis we used the statistical program IBM SPSS v.24 with a fixed significance level of $p<.05$.

\section{RESULTS}

Table 1 shows the results of anthropometry, physical tests and eating habits of physical education students according to the shift in which they are enrolled, expressed as mean and standard deviation.

As can be seen in the flexibility test, there is a significant difference, being it higher in students in the morning shift, while for the food survey, differences were observed in the consumption of fruits, vegetables, homemade food and dinner, observing significantly higher consumption in the morning shift; while the consumption of breakfast, legumes, whole foods, sugary drinks, fried foods, salt and snacks were higher in the students in night shift. Likewise, it is important to mention the differences in eating habits, being them greater in the students of the night shift.

The differences mentioned, the writers consider that it is due to the fact that students on the night shift generally work during the day, so they do not have the time to eat healthy foods.

Table 2 shows the correlations between anthropometry, physical tests and eating habits. Among the most relevant results, a direct, positive and significant correlation was observed between the RWH / dairy consumption; as well as in the flexibility / consumption of fruits and vegetables; BMI / fish consumption. On the other hand, there is an indirect, negative and significant correlation between flexibility / breakfast consumption; test of course Narvette / RWH and the consumption of vegetables and fruits; among others. 
From the aforementioned, those who write highlight that the consumption of fish, vegetables and other healthy foods are related to a lesser extent, but significantly, with certain physical tests such as the RWH, flexibility, etc.

Table 1. Anthropometry, physical tests and eating habits.

\begin{tabular}{lccc}
\hline Dimensions & Morning shift & Night shift & p-value \\
\hline Physical condition & $293.9 \pm 37.27$ & $292.04 \pm 38.37$ & .64 \\
\hline BMl (kg/m2) & $23.20 \pm 2.14$ & $23.45 \pm 1.95$ & .27 \\
RWH (cm) & $0.4426 \pm 0.01731$ & $0.04439 \pm 0.01794$ & .52 \\
Short abs (rep.) & $24.54 \pm 0.96$ & $24.64 \pm 0.95$ & .36 \\
Flexo-extension of elbows (rep.) & $35.1 \pm 2.3$ & $34.8 \pm 2.1$ & .17 \\
Long jump with feet together (cm) & $170.6 \pm 36.6$ & $168.2 \pm 37.7$ & .56 \\
Flexibility (cm) & $33.8 \pm 3.3$ & $28.7 \pm 5.5$ & .00 \\
Course Navette Test (min) & $7.49 \pm 1.72$ & $7.52 \pm 1.63$ & .89 \\
\hline Eating habits & $39.66 \pm 11.35$ & $42.67 \pm 11.36$ & .018 \\
\hline Breakfast consumption & $2.51 \pm 1.25$ & $3.5 \pm 1.26$ & .00 \\
Dairy consumption & $2.59 \pm 1.24$ & $2.75 \pm 1.25$ & .24 \\
Fruit consumption & $2.85 \pm 1.2$ & $2.37 \pm 1.1$ & .00 \\
Vegetables consumption & $3.36 \pm 1.17$ & $2.79 \pm 1.27$ & .00 \\
Fish consumption & $2.74 \pm 1.29$ & $2.81 \pm 1.3$ & .61 \\
Legume consumption & $2.58 \pm 1.33$ & $2.98 \pm 1.42$ & .08 \\
Consumption of whole-grain foods & $2.68 \pm 1.34$ & $3 \pm 1.34$ & .04 \\
Consumption of homemade food & $3.42 \pm 1.25$ & $2.83 \pm 1.33$ & .00 \\
Dinner consumption & $3.36 \pm 1.24$ & $2.61 \pm 1.38$ & .00 \\
Consumption of sugary drinks & $2.53 \pm 1.35$ & $3.11 \pm 1.38$ & .00 \\
Alcohol consumption & $2.24 \pm 1.27$ & $2.41 \pm 1.35$ & .24 \\
Consumption of fried foods & $2.48 \pm 1.28$ & $3.44 \pm 1.22$ & .00 \\
Salt intake & $2.06 \pm 0.84$ & $2.28 \pm 0.8$ & .02 \\
Fast food consumption & $2.57 \pm 1.29$ & $2.6 \pm 1.23$ & .84 \\
Snack consumption & $2.51 \pm 1.23$ & $3.17 \pm 1.28$ & .00 \\
\hline
\end{tabular}
Note: BMl: Body mass index; RWH: Ratio of waist diameter and height.

Table 2. Correlation between the dimensions of physical condition and eating habits.

\begin{tabular}{lllcccccc}
\hline & & BMI & RWH & $\begin{array}{c}\text { Short } \\
\text { abs }\end{array}$ & $\begin{array}{c}\text { Flexo elbow } \\
\text { extension }\end{array}$ & $\begin{array}{c}\text { Long jump } \\
\text { with feet } \\
\text { together }\end{array}$ & Flexibility & $\begin{array}{c}\text { Course } \\
\text { Narvette } \\
\text { test }\end{array}$ \\
\hline Breakfast & Pearson & .074 & .08 & -.071 & -.107 & .073 & $-.382^{* *}$ & .062 \\
consumption & $\mathrm{p}$ & .175 & .14 & .191 & .050 & .179 & .000 & .260 \\
Dairy & Pearson & .08 & $.419^{*}$ & -.034 & -.075 & -.027 & -.036 & -.036 \\
consumption & $\mathrm{p}$ & .144 & .00 & .536 & .170 & .623 & .510 & .512 \\
Fruit & Pearson & .035 & -.01 & -.025 & -.063 & -.081 & $.229^{* *}$ & -.088 \\
consumption & $\mathrm{p}$ & .527 & .89 & .647 & .246 & .137 & .000 & .106 \\
Vegetables & Pearson & -.03 & $-.31^{* *}$ & .028 & -.104 & -.090 & $.344^{* *}$ & $-.137^{*}$ \\
consumption & $\mathrm{p}$ & .588 & .00 & .615 & .056 & .097 & .000 & .012 \\
Fish & Pearson & $.122^{*}$ & $.212^{*}$ & .043 & -.091 & -.031 & .063 & -.047 \\
consumption & $\mathrm{p}$ & .025 & .00 & .427 & .094 & .570 & .250 & .394 \\
\hline
\end{tabular}




\begin{tabular}{|c|c|c|c|c|c|c|c|c|}
\hline Legume & Pearson & .06 & $.258^{*}$ & -.013 & -.005 & -.047 & $-.127^{*}$ & -.014 \\
\hline consumption & $p$ & .27 & .00 & .816 & .931 & .386 & .019 & .797 \\
\hline Consumption & Pearson & .09 & $.275^{*}$ & $.140^{*}$ & $-.117^{*}$ & $-.108^{*}$ & -.017 & -.086 \\
\hline of whole foods & $p$ & .09 & .00 & .010 & .031 & .047 & .760 & .116 \\
\hline Consumption & Pearson & -.01 & $-.16^{* *}$ & .040 & -.059 & $-.124^{*}$ & $.311^{* *}$ & -.074 \\
\hline $\begin{array}{l}\text { of homemade } \\
\text { food }\end{array}$ & $p$ & .93 & .00 & .466 & .280 & .023 & .000 & .177 \\
\hline $\begin{array}{l}\text { Dinner } \\
\text { consumption } \\
\text { Consumption }\end{array}$ & $\begin{array}{l}\text { Pearson } \\
p \\
\text { Pearson }\end{array}$ & $\begin{array}{l}.06 \\
.22 \\
.09\end{array}$ & $\begin{array}{l}-.25^{* \star} \\
.00 \\
.06\end{array}$ & $\begin{array}{l}-.049 \\
.369 \\
.088\end{array}$ & $\begin{array}{l}-.035 \\
.516 \\
-.059\end{array}$ & $\begin{array}{c}-.100 \\
.066 \\
-.192^{\star *}\end{array}$ & $\begin{array}{l}.316^{\star *} \\
.000 \\
-.190^{\star *}\end{array}$ & $\begin{array}{c}-.061 \\
.263 \\
-.154^{\star *}\end{array}$ \\
\hline $\begin{array}{l}\text { of } \\
\text { drinks }\end{array}$ & $p$ & .07 & .25 & .108 & .280 & .000 & .000 & . 005 \\
\hline Alcohol & Pearson & .00 & .02 & .088 & -.063 & $-.137^{*}$ & .048 & $-.115^{*}$ \\
\hline consumption & $p$ & .96 & .66 & .109 & .247 & .012 & .380 & .036 \\
\hline $\begin{array}{l}\text { Consumption } \\
\text { of fried foods }\end{array}$ & $\begin{array}{l}\text { Pearson } \\
p\end{array}$ & $\begin{array}{l}.12^{*} \\
.02\end{array}$ & $\begin{array}{l}.27^{*} \\
.00\end{array}$ & $\begin{array}{l}.115^{*} \\
.035\end{array}$ & $\begin{array}{l}.025 \\
.645\end{array}$ & $\begin{array}{l}-.08 \\
.103\end{array}$ & $\begin{array}{l}-.27^{* *} \\
.000\end{array}$ & $\begin{array}{l}-.04 \\
.387\end{array}$ \\
\hline Salt intake & Pearson & .00 & .01 & .065 & .009 & -.01 & -.10 & .011 \\
\hline Fast food & Pearson & .00 & .00 & .083 & .068 & -.02 & .076 & .045 \\
\hline consumption & $p$ & .54 & .96 & .127 & .212 & 696 & 161 & .414 \\
\hline Snack & Pearson & .02 & $.122^{*}$ & $.191^{\star *}$ & -.01 & -.04 & $-.17^{* *}$ & -.02 \\
\hline consumption & $p$ & .70 & .02 & .000 & .800 & .413 & .001 & .660 \\
\hline
\end{tabular}

As can be seen in Figure 1, the physical condition variable is not related to eating habits. Also, according to Pearson's correlation, it is an indirect, negative and significant correlation with a value of -.111.

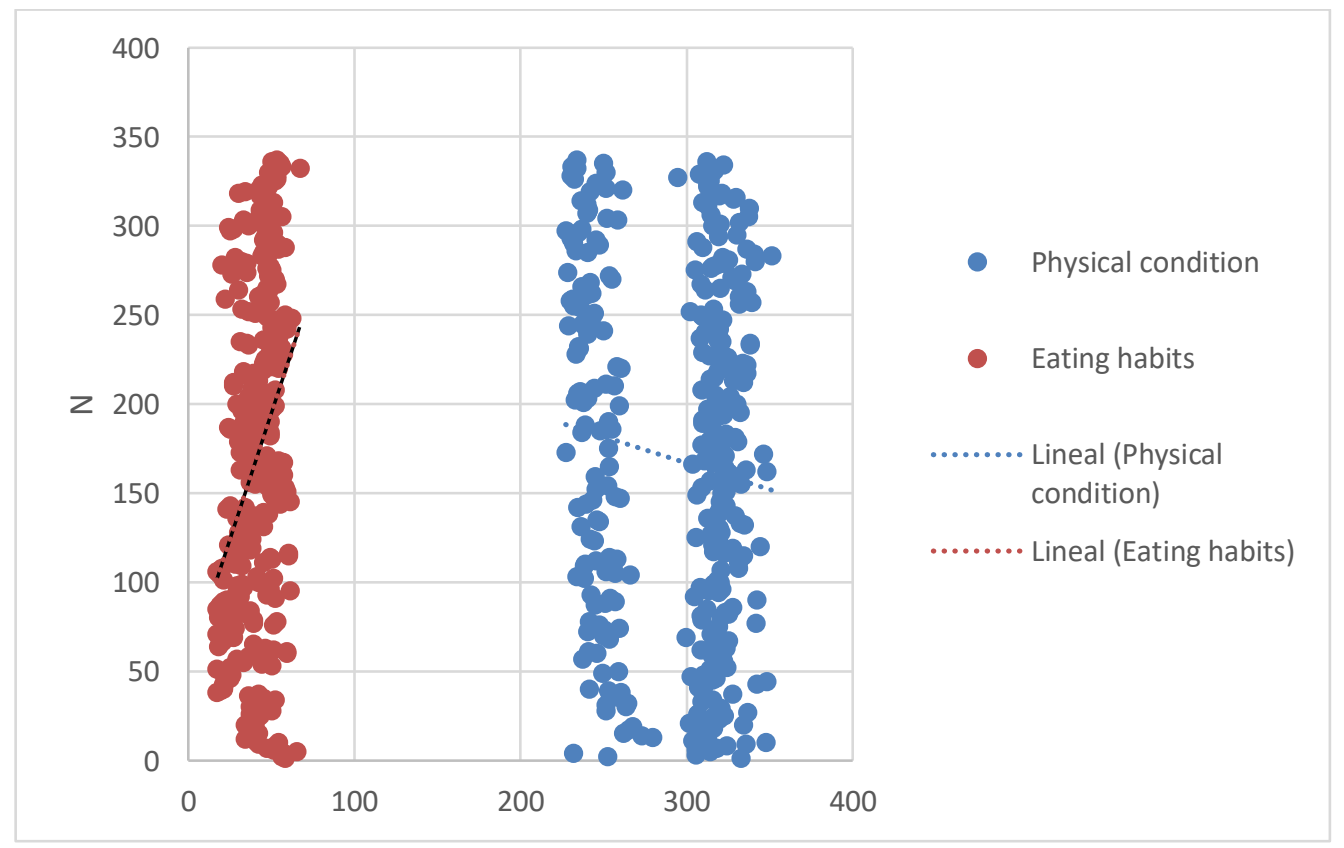

Figure 1. Relationship between physical condition and eating habits. 


\section{DISCUSSION}

The research objectives were: 1) to identify the physical condition and eating habits per shift, 2) to compare the variables and dimensions per shift, 3) to determine the relationships between the variables and dimensions. The main conclusions of the research were that there is a difference in eating habits, being it significantly higher in students in the night shift; likewise, when finding the correlations between the dimensions of each variable, it was observed that the consumption of fish, vegetables and other healthy foods are related to a lesser extent, but significantly, with certain physical tests such as the RWH, flexibility, etc. Finally, there was an indirectly significant correlation between physical condition and eating habits. These results are similar to Driskell et al. (2005), who observed significant differences between the first cycles and last cycles of one in the frequency of eating snacks frequency of eating in the cafeterias of the university, as well as frequency of performance of other aerobic and physical activities. Also, with Marcondelli et al. (2008) who observed a high level of inactivity among students. Besides, the lowest levels in terms of acceptable nutrition were observed for the group derived from milk $(23.0 \%)$, fruits and vegetables $(24.9 \%)$ as well as carbohydrates (25.9\%). A high percentage of inappropriate consumption of soft drinks was observed $(74.0 \%)$. In addition to Sakamaki et al. (2005), who identified that $47.9 \%$ of the students reported consuming vegetables and $32.5 \%$ of the individuals described consuming fruit daily. Girl students tend to eat more fruit than men. With regard to anthropometry, $80.5 \%$ of the students had a normal BMI and $16.6 \%$ of the students were underweight. Lastly, Grygiel-Górniak et al. (2016) identified that students with a higher level of physical activity consumed lower amounts of simple carbohydrates (galactose and sucrose) compared to students who do less physical activity.

It is important to mention that among the limitations of the research there was a lack of interest on the part of the students to carry out the physical tests and the questionnaire; therefore, we proceeded to report on the benefits of this research for both students and the university.

Another limitation is related to the fact that the study sample does not reflect $100 \%$ of the students; therefore, there could be fluctuations in the results if a larger sample is chosen.

\section{CONCLUSIONS}

Among the main conclusions of the research are the following: a) the physical condition in the morning and night shifts are similar, b) there was a significant difference in eating habits, being it greater in the students of the night shift, c) There was a direct relationship between the consumption of healthy foods and physical tests in both study shifts. It is recommended to provide the corresponding importance in terms of the study variables.

\section{ACKNOWLEDGEMENTS}

The authors wish to thank the students who participated in the collection of questionnaires, as well as all the participants for their collaboration in the study.

\section{REFERENCES}

Agency for the Quality of Education (2014). Retrieved on January 11, 2021, from Results Report. National Study of Physical Education 2013: 
http://archivos.agenciaeducacion.cl/biblioteca_digital_historica/resultados/2013/result8b_edfisica_2 013.pdf

Atamari, N., Ccorahua, M. S., Taype, A. and Mejia, C. R. (2018). Mortality attributed to diabetes mellitus registered in the Ministry of Health of Peru, 2005-2014. Amer J Public Health (42), e50. http://doi.org/10.26633/RPSP.2018.50

Balanzá - Martínez, V., Atienza - Carbonell, B., Kapczinski, F. and De Boni, R. B. (2020). Lifestyle behaviors during the COVID-19 - time to connect. Act Psych Sc, 41 (5), 399-400. http://doi.org/10.1111/acps.13177

Basco, J. (2014). Sports massage and its influence on muscle performance. (Doctoral Thesis). University of Castillo-La Mancha, Spain. Retrieved from http://hdl.handle.net/10578/3956

Beiter, R., Nash, R., McCrady, M., Rhoades, D., Linscomb, M., Clarahan, M. and Sammut, S. (2015). The prevalence and correlates of depression, anxiety, and stress in a sample of college students. J affect disorders (173), 90-96. http://doi.org/10.1016/j.jad.2014.10.054

Burke, S. M., Carron, A. V. and Eys, M. A. (2006). Physical activity context: Preferences of university students. Psychol Sport Exerc, 7 (1), 1-13. https://doi.org/10.1016/j.psychsport.2005.03.002

Burriel, C., Serrano, V. and Tobrra. (2013). Food habits and nutritional assessment in a university population. Hos Nutr, 28 (2), 438-446. https://doi.org/10.3305/nh.2013.28.2.6303

Demirci, N., Demirci, P. T. and Demirci, E. (2018). The Effects of Eating Habits, Physical Activity, Nutrition Knowledge and Self-Efficacy Levels on Obesity. Universal J Educ Res, 6 (7), 1424-1430. https://doi.org/10.13189/ujer.2018.060702

Di Renzo, L., Gualtieri, P., Pivari, F., Soldati, L., Attinà, A., Cinelli, G.,. . . Lorenzo, A. (2020). Eating habits and lifestyle changes during COVID-19 lockdown: an Italian survey. J Transl Med (18), 1-15. https://doi.org/10.1186/s12967-020-02399-5

Draga, P., Ozimek, M., Krawczyk, M., Rokowski, R., Nowakowska, M., Ochwat, P.,... Stanula, A. (2020). Importance and Diagnosis of Flexibility Preparation of Male Sport Climbers. Int J Env Res Pub He, 17 (7), 2512. https://doi.org/10.3390/ijerph17072512

Driskell, J., Kim, Y. and Goebel, K. (2005). Few Differences Found in the Typical Eating and Physical Activity Habits of Lower-Level and Upper-Level University Students. J Am Diet Assoc, 105 (5), 798801. https://doi.org/10.1016/j.jada.2005.02.004

Durán, S., Valdés, P., Godoy, A. and Herrera, T. (2014). Eating habits and physical condition in students of pedagogy in physical education. Chil J Nutr, 41 (3), 251-259. https://doi.org/10.4067/S071775182014000300004

El Ansari, W., Stock, C. and Mikolajczyk, R. (2012). Relationships between food consumption and living arrangements among university students in four European countries - A cross-sectional study. Nutr J, 11 (1), 28. https://doi.org/10.1186/1475-2891-11-28

García, G. C. and Secchi, J. D. (2014). Test course navette of 20 meters with one minute stages. An original idea that has lasted 30 years. Apunts. Medicine de l'Esport, 49 (183), 93-103. https://doi.org/10.1016/i.apunts.2014.06.001

Grygiel-Górniak, B., Tomczak, A., Krulikowska, N., Przysławski, J., Seraszek-Jaros, A. and Kaczmarek, E. (2016). Physical activity, nutritional status, and dietary habits of students of a medical university. Sport sci health, 12 (2), 261-267. https://doi.org/10.1007/s11332-016-0285-x

Janssen, I., Katzmarzyk, P. T., Boyce, W. F., King, M. A. and Pickett, W. (2004). Overweight and obesity in Canadian adolescents and their associations with dietary habits and physical activity patterns. $J$ adolescent health, 35 (5), 360-367. https://doi.org/10.1016/j.jadohealth.2003.11.095

Kilpatrick, M., Hebert, E. and Bartholomew, J. (2005). College Students' Motivation for Physical Activity: Differentiating Men's and Women's Motives for Sport Participation and Exercise. J Am Coll Health, 54 (2), 87-94. https://doi.org/10.3200/JACH.54.2.87-94 
López, M., Iglesias, M., Miguel, M. and Garcés, M. (2020). Physical and Psychological Effects Related to Food Habits and Lifestyle Changes Derived from COVID-19 Home Confinement in the Spanish Population. Nutrients, 12 (11), 3445. https://doi.org/10.3390/nu12113445

Marcondelli, P., Macedo, T. and Soares, B. (2008). Level of physical activity and eating habits of university students from 3rd to 5th semesters of the health area. Rev Nutrição, 21 (1), 39-47. https://doi.org/10.1590/S1415-52732008000100005

Mattioli, A. V., Puviani, M. B., Nasi, M. and Farinetti, A. (2020). COVID-19 pandemic: the effects of quarantine on cardiovascular risk. Eur J Clin Nutr, 74(6), 852-855. https://doi.org/10.1038/s41430020-0646-z

Mori, S. C. (2000). Addressing the mental health concerns of international students. J couns dev, 78(2), 137-144. https://doi.org/10.1002/j.1556-6676.2000.tb02571.x

Navarrete, P. J., Vega, E., Pareja, A. and Benites, J. C. (2019). Factores asociados al sedentarismo en jóvenes estudiantes de educación superior. Perú, 2017. Med Horizons, 19(1), 46-52. https://doi.org/10.24265/horizmed.2019.v19n1.08

Pajuelo, J. (2017). La obesidad en el Perú. Ann Med Faculty, 78(2), 179-185. https://doi.org/10.15381/anales.v78i2.13214

Papadaki, A., Hondros, G., Scott, J. A. and Kapsokefalou, M. (2007). Eating habits of University students living at, or away from home in Greece. Appetite, 49(1), 169-176. https://doi.org/10.1016/.appet.2007.01.008

Sakamaki, R., Toyama, K., Amamoto, R., Liu, C. J. and Shinfuku, N. (2005). Nutritional knowledge, food habits and health attitude of Chinese university students -a cross sectional study. Nutr J, 4(1), 4. https://doi.org/10.1186/1475-2891-4-4

Sheppard, V. (2020). Research Methods for the Social Sciences: An Introduction. Vancouver: BCCampus.

Ulijaszek, S. J., \& Mascie-Taylor, C. N. (2005). Anthropometry: the individual and the population. Inglaterra: Cambridge University Press.

Valdes, P., Godoy, A., Herrera, T. and Durán, S. (2015). The comparison between food habits and physical condition among physical education and other undergraduate students. Hosp Nutr, 32(2), 829-836. http://doi.org/10.3305/nh.2015.32.2.9194

Yarmak, O., Blagii, O., Palichuk, Y., Hakman, A., Balatska, L., Moroz, O. and Galan, Y. (2018). Analysis of the factor structure of the physical condition of girls 17-19 year-old. J Hum Sport Exerc, 13(2), S259-S268. https://doi.org/10.14198//hse.2018.13.Proc2.11

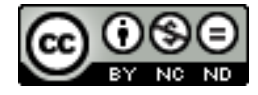

This work is licensed under a Attribution-NonCommercial-NoDerivatives 4.0 International (CC BY-NC-ND 4.0). 